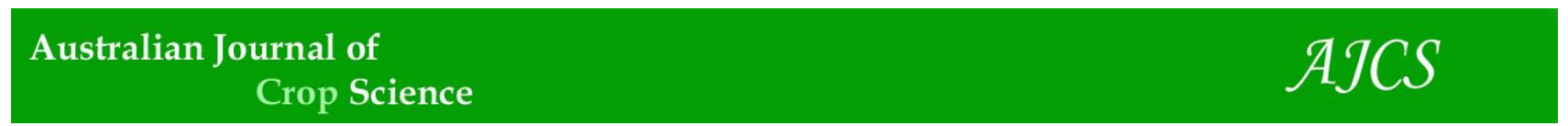

AJCS 14(07):1095-1101 (2020)

ISSN:1835-2707

doi: 10.21475/ajcs.20.14.07.p2241

\title{
Post-emergence application of glufosinate on maize hybrids containing the phosphinothricin acetyltransferase gene (pat)
}

\author{
Fábio Henrique Krenchinski ${ }^{*}$, Caio Antonio Carbonari, Edicarlos Batista de Castro, Danilo Morilha \\ Rodrigues, Victor José Salomão Cesco, Renato Nunes Costa, Edivaldo Domingues Velini
}

\author{
Department of Plant Breeding and Production, São Paulo State University (UNESP), School of Agriculture, Botucatu, \\ Brazil
}

*Corresponding author: fhkrenchinski@gmail.com

\begin{abstract}
Several maize hybrids that present the phosphinothricin acetyltransferase gene (pat) are available in the market. However, these hybrids have different resistance levels to glufosinate herbicides. The objective of the present work was to evaluate the resistance of maize hybrids containing the pat gene (as a selection marker) to glufosinate. Field experiments were conducted in two sites in the 2016/2017 crop season, using a randomized block design with a $2 \times 7$ factorial arrangement and four replications. The treatments consisted of two glufosinate rates $\left(0\right.$ and $\left.500 \mathrm{~g} \mathrm{ha}^{-1}\right)$ and seven maize hybrids, six containing the pat gene as a selection marker (Herculex, Agrisure-TL ${ }^{\circ}$, Herculex Yieldgard, Leptra ${ }^{\circ}$, Viptera- $3^{\circ}$, and Power-Core ${ }^{\circ}$ ) and one without the pat gene (VT $P R 0^{\circ}$ ). Two field experiments were conducted in different sites. The analyzed variables were: ammonia accumulation, electron transport rate (ETR), percentage of injuries, 100-grain weight, and grain yield. The glufosinate-susceptible maize hybrid presented higher ammonia accumulations, lower ETR, and high percentage of injuries (100\%), which caused total loss of grain production. Considering the evaluated glufosinate-resistant maize hybrids, Viptera-3 and Agrisure-TL presented the highest ammonia accumulations and percentages of injuries, and lower ETR than the other hybrids. The grain yield of glufosinate-resistant maize hybrids was not reduced due to the application of the $500 \mathrm{~g} \mathrm{ha}^{-1}$ of glufosinate. Thus, glufosinate-resistant maize hybrids containing the pat gene are resistant to the application of $500 \mathrm{~g} \mathrm{ha}^{-1}$ of glufosinate, and this practice can be recommended for maize crops.
\end{abstract}

Keywords: pat gene, L-phosphinothricin, ammonium accumulation, electron transport rate, Zea mays L.

Abbreviations: ETR_electron transport rate; GS_glutamine synthase; PAT_phosphinothricin acetyltransferase enzyme; pat_ phosphinothricin acetyltransferase gene.

\section{Introduction}

The glufosinate herbicide is derived from a phosphinothricin, which is isolated from the Streptomyces viridochromogenes and Streptomyces hygroscopicus fungi (Dayan et al., 2009; Dayan and Duke, 2014). It is a nonselective post-emergence herbicide of broad spectrum of weed control that inhibits the glutamine synthetase (GS) enzyme (EC 6.3.1.2). GS promotes ammonia detoxification, and production of the glutamine amino acid from ammonia and glutamate (Barnett et al., 2012). After glufosinate application and GS inhibition, susceptible plants present glutamine deficiency, rapid ammonia and glyoxylate accumulation, disruption of chloroplast structures, decreases in electron transport rate (ETR), and changes in fluorescence emission (Dayan et al., 2015; Carbonari et al., 2016; Devine et al., 1993; Coetzer and Al-Khatib, 2001). Resistance of maize hybrids to glufosinate can be achieved through the insertion of the phosphinothricin acetyltransferase (pat) gene from Streptomyces viridochromogenes. When this gene is transcribed in the plant, it produces the PAT enzyme, which metabolizes the glufosinate herbicide in n-acetyl-Lglufosinate (NAG) (Droge et al., 1994). The pat gene was inserted in maize plants as a selection marker and presented expression of genes associated with resistance to insects
(CTNbio 2018). Two events containing the pat gene as a selection marker were launched in Brazil (Bt11 and TC1507), which present differences in the construction of the plasmid. The plasmids used were: pZO1502 in Bt11, and PHI899A in TC1507 (CTNbio 2018). This difference in plasmid construction can lead to changes in expression and site of gene insertion in the plants (Cui et al., 2016) and, consequently, it can generate different levels of resistance to the glufosinate herbicide (Carbonari et al., 2016). In Brazil, maize hybrids with the pat gene (resistant to glufosinate) from the Bt11 and TC1507 events are marketed to maize producers. Glufosinate application in these hybrids can present good weed control results, but it is not recommended by companies that market these materials. However, there is little information about the Bt11 and TC1507 events. Glufosinate applications at $500 \mathrm{~g} \mathrm{ha}^{-1}$ in Power-Core ${ }^{\circledR}$ maize (TC1507 event) have shown no effect on grain yield and physiological parameters (Krenchinski et al., 2018a; Silva et al., 2017). Glufosinate-resistant maize hybrids present different resistance levels (Krenchinski et al., 2018b), making it difficult to recommend the use of glufosinate. Cotton plants with the Liberty Link ${ }^{\circ}$ technology had greater expression of the phosphinothricin 
acetyltransferase (bar) gene than plants with the WideStrike technology (pat gene) (Carbonari et al., 2016). Thus, Liberty Link plants, which were developed for resistance to glufosinate, are more resistant than WideStrike plants, which were developed to use the pat gene as a selection marker (Carbonari et al., 2016). The use of glufosinate herbicide on maize to control glyphosateresistant weeds are increasing; however, little information is found about the possible glufosinate damages on maize plants that present the pat gene as a selection marker. Thus, studies are needed to make the recommendation of this herbicide clear and feasible and to provide information on ammonia accumulation, physiology, and grain yield of maize plants from different hybrids. In this context, the objective of the present work was to evaluate the resistance of maize hybrids containing the pat gene to the glufosinate herbicide.

\section{Result and Discussion}

\section{Ammonia Content in maize hybrids}

After the glufosinate application, the glufosinate-susceptible maize hybrid had 17 -fold to 40 -fold higher ammonia accumulation than the control without application, differing from the glufosinate-resistant maize hybrids at 2, 4, and 15 days after application (DAA). Considering the glufosinateresistant maize hybrids, Viptera-3 and Agrisure-TL presented 4-fold to 5-fold higher ammonia accumulations than the Power-Core and Leptra hybrids at 2 DAA, and 2-fold to 3-fold higher ammonia accumulations at 4 DAA. All evaluated glufosinate-resistant maize hybrids had similar ammonia accumulation at 15 DAA (Fig 2), denoting that accumulation of ammonia may occur in maize plants even with the presence of the pat gene (Krenchinski et al., 2018b).The glufosinate application increased ammonia accumulation of glufosinate-resistant maize plants (Fig 2) due to the permanent binding of glufosinate to the glutamine synthetase (GS) enzyme (Dayan et al., 2015; Sellers et al., 2004; Coetzer and Al-Khatib, 2001). Glufosinate application on non-transgenic species also results in intense accumulation of ammonia, as observed in Ipomoea grandifolia (Brito et al., 2017a), Commelina benghalensis (Brito et al., 2017b), Bidens pilosa (Brito et al., 2016), Chenopodium album, Solanum nigrum, Tripleurospermum inodorum, Echinochloa crus-galli (Manderscheid et al., 2005); Abutilon theophrasti (Sellers et al., 2004), Amaranthus palmeri (Coetzer and Al-Khatib, 2001), maize (Pornprom, et al. 2003), and eucalyptus (Krenchinski et al., 2018c). The decrease in ammonia levels in glufosinateresistant maize hybrids between 2 DAA and 4 DAA is due to the rapid degradation of glufosinate into NAG by the PAT enzyme, which does not bind to GS and is not toxic to plants (Krenchinski et al., 2018b; Carbonari et al., 2016; Ruhland et al., 2004; Droge et al., 1994). Maize, Cotton, rice, tobacco, and sugar beet plants containing the pat or bar genes also present ammonia accumulation after glufosinate application at rates of approximately $500 \mathrm{~g} \mathrm{ha}^{-1}$, but with lower accumulation than their controls without these genes (Krenchinski et al., 2018b; Carbonari et al., 2016; Lutz et al., 2011; Tsai et al., 2006; Dröge et al., 1994).

\section{Electron transport rate (ETR) in maize hybrids}

The ETR of the Viptera- 3 and Agrisure-TL hybrids decreased at six hours after application (40\%-45\%) and at 1 DAA (12\%) when compared to the other hybrids with the pat gene.
However, the ETR was normalized (approximately 100\%) from 2 DAA. The ETR of the other evaluated glufosinateresistant maize hybrids was not affected by the application of $500 \mathrm{~g} \mathrm{ha}^{-1}$ of glufosinate. The glufosinate-susceptible maize hybrid had decreases in ETR throughout the evaluated period, reaching values close to zero at 8 DAA (Fig 3).

ETR evaluations can estimate damages in plants after glufosinate application. Glufosinate application decreases ETR, especially in glufosinate-susceptible maize hybrid, due to GS inhibition, ammonia accumulation, chloroplast disruption, and inhibition of protein synthesis, especially $Q b$, which is directly involved with the transport of electrons in the plant (Tan et al., 2006; Dayan and Zaccaro, 2012; Devine et al., 1993; Kleczkowski, 1993; Sauer et al., 1987). Plants with containing the pat gene are less affected by the inhibitory effects of glufosinate (Krenchinski et al., 2018b; Carbonari et al., 2016; Ruhland et al., 2004; Droge et al., 1994), especially the effects on the ETR. Effects on ERT decreased at 6 hours after application and at 1 DAA in the Viptera-3 and Agrisure-TL hybrids, with rapid recovery to similar levels to the control without application. Decreases in ETR were also observed in cotton plants containing the bar and pat genes (Carbonari et al., 2016), in soybean plants with the pat gene (Reddy et al., 2011), and in glufosinateresistant maize hybrids (Krenchinski et al., 2018b), compared to their respective non-transgenic plants.

\section{Injuries in maize hybrids}

The application of $500 \mathrm{~g} \mathrm{ha}^{-1}$ of glufosinate in glufosinateresistant maize hybrids caused slight injuries to the plants, regardless of the evaluation period. Viptera-3 and AgrisureTL hybrids had the highest percentages of injuries $(10 \%$ and $12 \%$, respectively). The percentage of injuries of the control plants of the glufosinate-susceptible maize hybrid was high at all evaluation times; these plants presented injuries of $100 \%$ (death) at 21 DAA (Fig 4). The percentage of injuries of Viptera-3 and Agrisure-TL were consistent with their ammonia accumulation (Fig 2) and ETR (Fig 3). Injuries of $4 \%$ to $6 \%$ had already been found in glufosinate-resistant maize hybrids subjected to application of $500 \mathrm{~g} \mathrm{ha}^{-1}$ of glufosinate (Krenchinski et al., 2018a, 2018b; Silva et al., 2017); and injury of $1 \%$ was found with application of $350 \mathrm{~g} \mathrm{ha}^{-1}$ of glufosinate (Armel et al., 2008). The glufosinate-susceptible maize hybrid evaluated in the present study had significant decreases in ETR (Fig 3) and increases in ammonia accumulation (Fig 2), which resulted in severe injuries and, consequently, death of the plants. The different ammonia accumulation, ETR, and percentage of injuries found in the glufosinate-resistant maize hybrids (Fig 2, 3, and 4) denote the different resistance levels to glufosinate of these hybrids. According to the results of the evaluated glufosinate-resistant maize hybrids, Viptera-3 and AgrisureTL can be classified as less resistant to glufosinate, and Leptra and Power-Core can be classified as the most resistant. The Viptera-3 and Agrisure-TL hybrids are from the Bt11 event, which included the pat gene using the pZO1502 plasmid; and the Leptra and Power-Core are from the TC1507 event, which included the pat gene using the PHI899A plasmid. Thus, the plasmid possibly interferes in the expression of the pat gene, which resulted in less glufosinate metabolism and more evident effects of glufosinate in the Viptera-3 and Agrisure-TL plants (Krenchinski et al., 2018b; CTNbio, 2018; Cui et al., 2016). This result was also found for cotton hybrids. 
Table 1. Soil chemical and physical properties of the experimental areas (Botucatu and São Manuel), SP, Brazil.

\begin{tabular}{|c|c|c|c|c|c|c|c|c|c|c|}
\hline \multicolumn{11}{|c|}{ Chemical properties } \\
\hline \multirow{2}{*}{$\begin{array}{l}\text { Experimental } \\
\text { area }\end{array}$} & \multirow{2}{*}{$\begin{array}{l}\mathrm{pH} \\
\mathrm{CaCl}_{2}\end{array}$} & \multirow{2}{*}{$\begin{array}{l}\mathrm{OM} \\
\mathrm{g} \mathrm{dm}^{-3}\end{array}$} & \multirow{2}{*}{$\begin{array}{l}P_{\text {resin }} \\
\mathrm{mg} \mathrm{dm}^{-3}\end{array}$} & $\mathrm{Al}$ & K & $\mathrm{Ca}$ & $\mathrm{Mg}$ & SB & CEC & $\mathrm{BS}$ \\
\hline & & & & \multicolumn{7}{|c|}{$\mathrm{mmol}_{\mathrm{c}} \mathrm{dm}^{-3}$} \\
\hline Botucatu & 5.1 & 21 & 21.6 & 1 & 4.3 & 30 & 13 & 48 & 98 & 59 \\
\hline São Manuel & 4.9 & 5 & 27 & 1 & 3.4 & 15 & 6 & 25 & 37 & 50 \\
\hline \multicolumn{11}{|c|}{ Physical properties } \\
\hline \multirow{2}{*}{$\begin{array}{l}\text { Experimental } \\
\text { area }\end{array}$} & Sand & Silt & Clay & \multirow{2}{*}{\multicolumn{2}{|c|}{ Texture }} & & & & & \\
\hline & $\mathrm{g} \mathrm{kg}^{-1}$ & & & & & & & & & \\
\hline Botucatu & 195 & 278 & 527 & \multicolumn{7}{|c|}{ Clayey } \\
\hline São Manuel & 844 & 39 & 117 & \multicolumn{7}{|c|}{ Sandy } \\
\hline
\end{tabular}

$\mathrm{OM}=$ organic matter; $\mathrm{SB}=$ sum of bases; $\mathrm{CEC}$ = cation exchange capacity; $\mathrm{BS}$ = base saturation
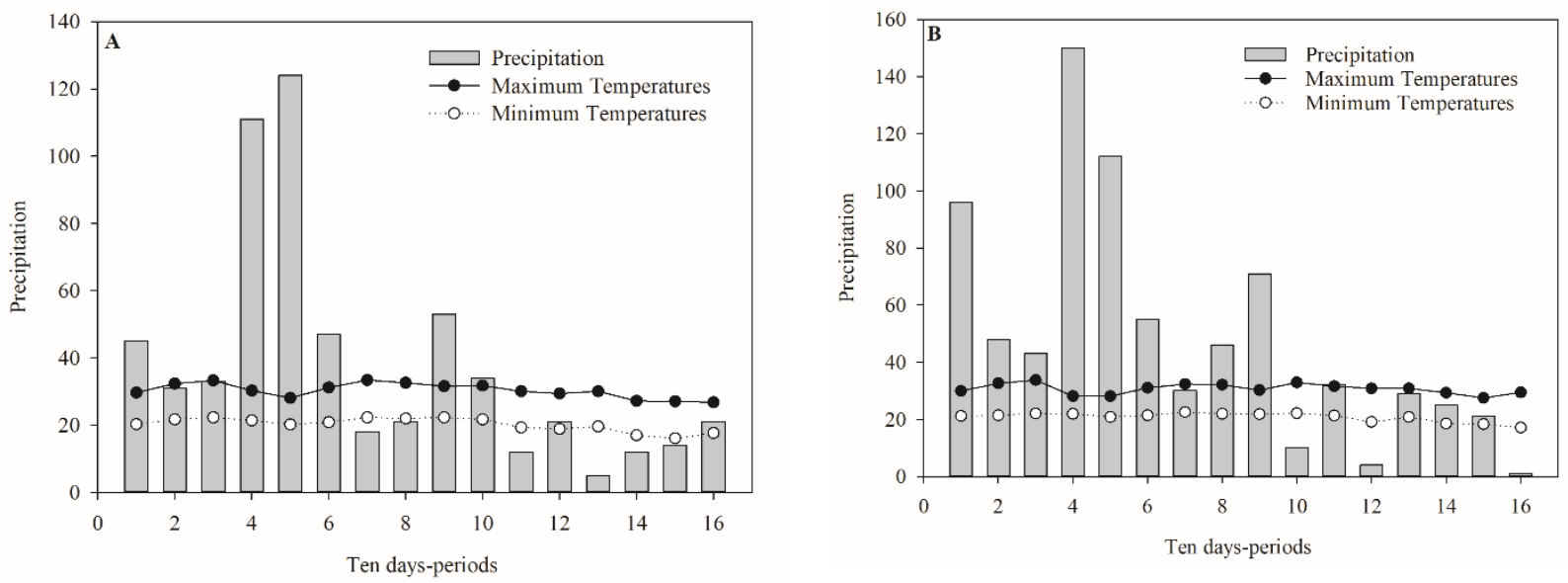

Fig 1. Precipitation and average minimum and maximum temperatures in the $2016 / 2017$ maize crop season in Botucatu, SP, Brazil (A) and in São Manuel, SP, Brazil (B). Source: Botucatu and São Manuel experimental farms of the São Paulo State University (UNESP), School of Agriculture, Brazil.

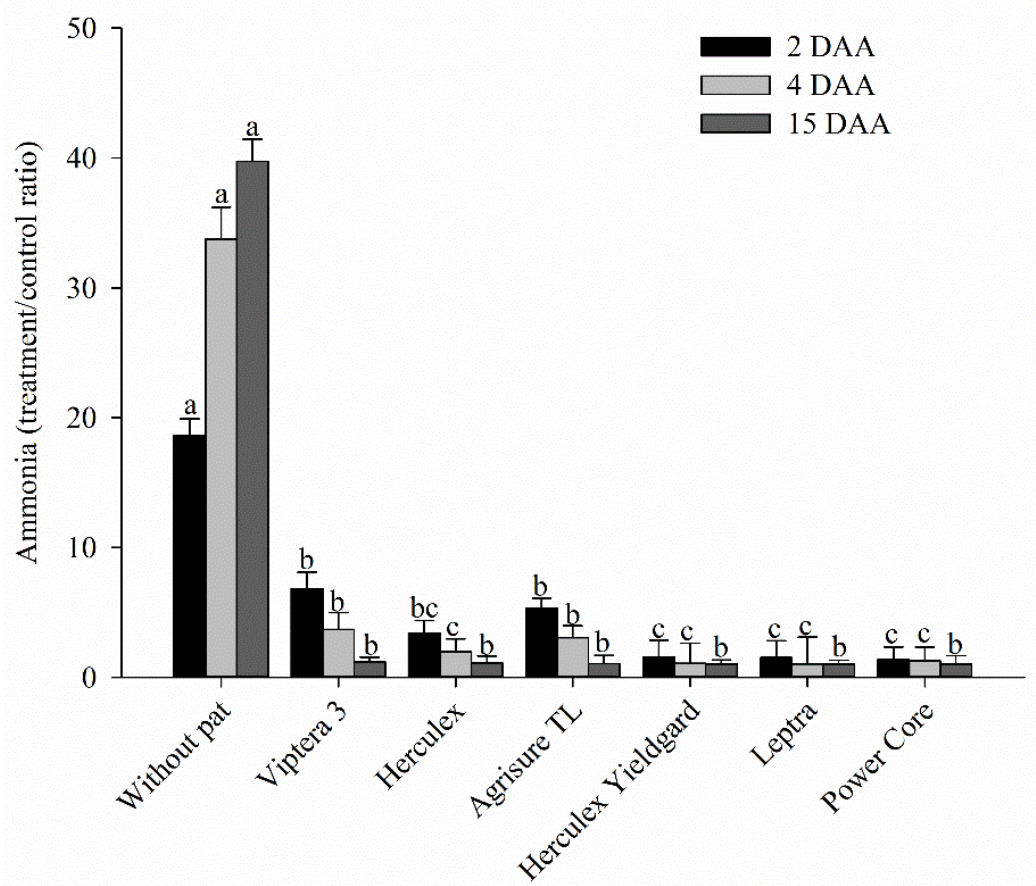

Fig 2. Ammonia accumulation in plants of seven maize hybrids in relation to the control (without glufosinate application) evaluated at 2, 4, and 15 days after application of $500 \mathrm{~g} \mathrm{ha}^{-1}$ of glufosinate. pat = phosphinothricin acetyltransferase gene. Bars with the same letters (comparing evaluation times or maize hybrids) did not differ by the $t$ test (LSD) $(p<0.05)$. Mean \pm confidence interval. 


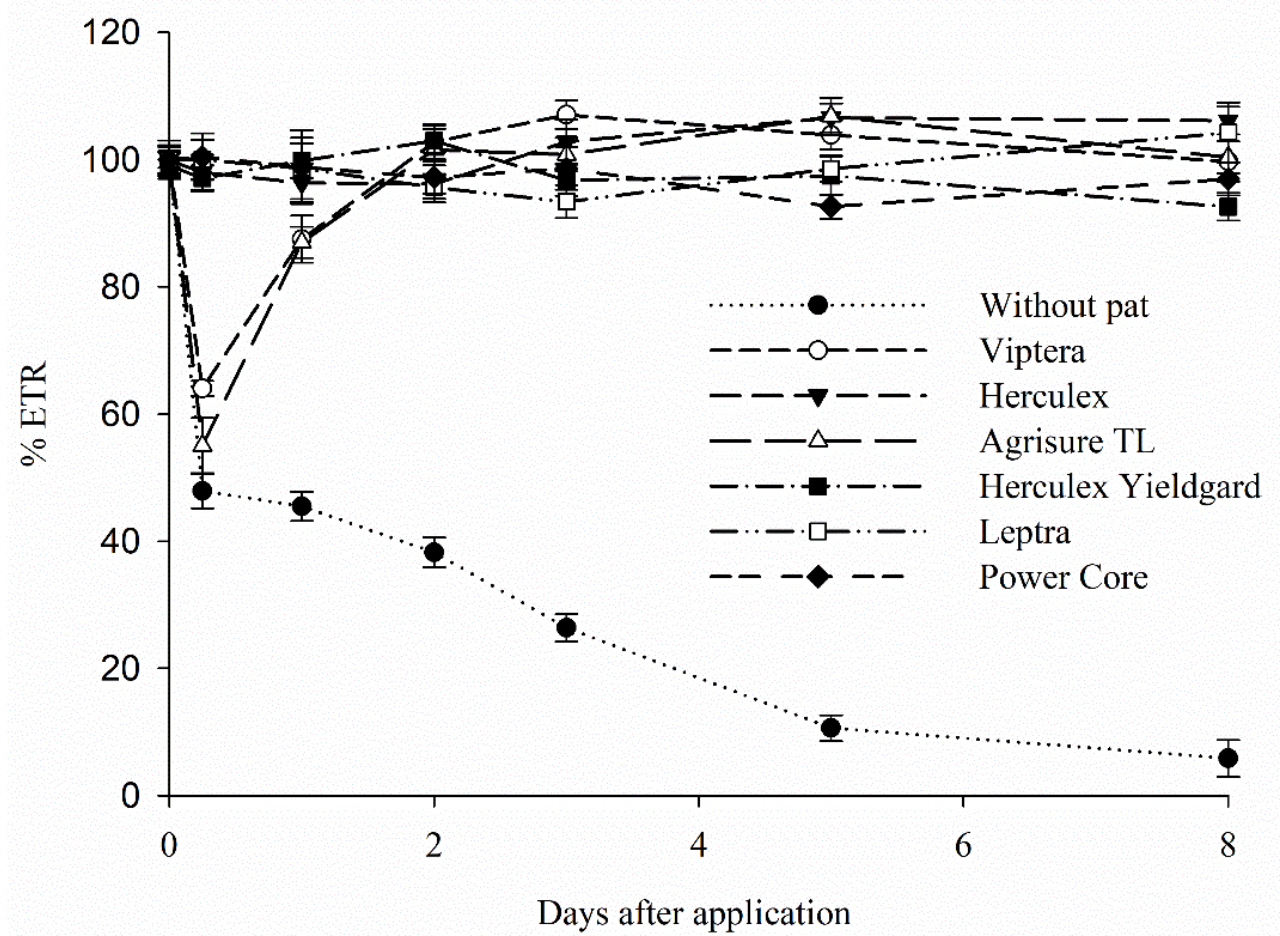

Fig 3. Electron transport rate (\%) in plants of seven maize hybrids with application of $500 \mathrm{~g} \mathrm{ha}{ }^{-1}$ of glufosinate in relation to the control (without glufosinate application) evaluated at 0 and 6 hours after application and at 1, 2, 3, 5, and 8 days after application. pat $=$ phosphinothricin acetyltransferase gene. Mean \pm confidence interval.

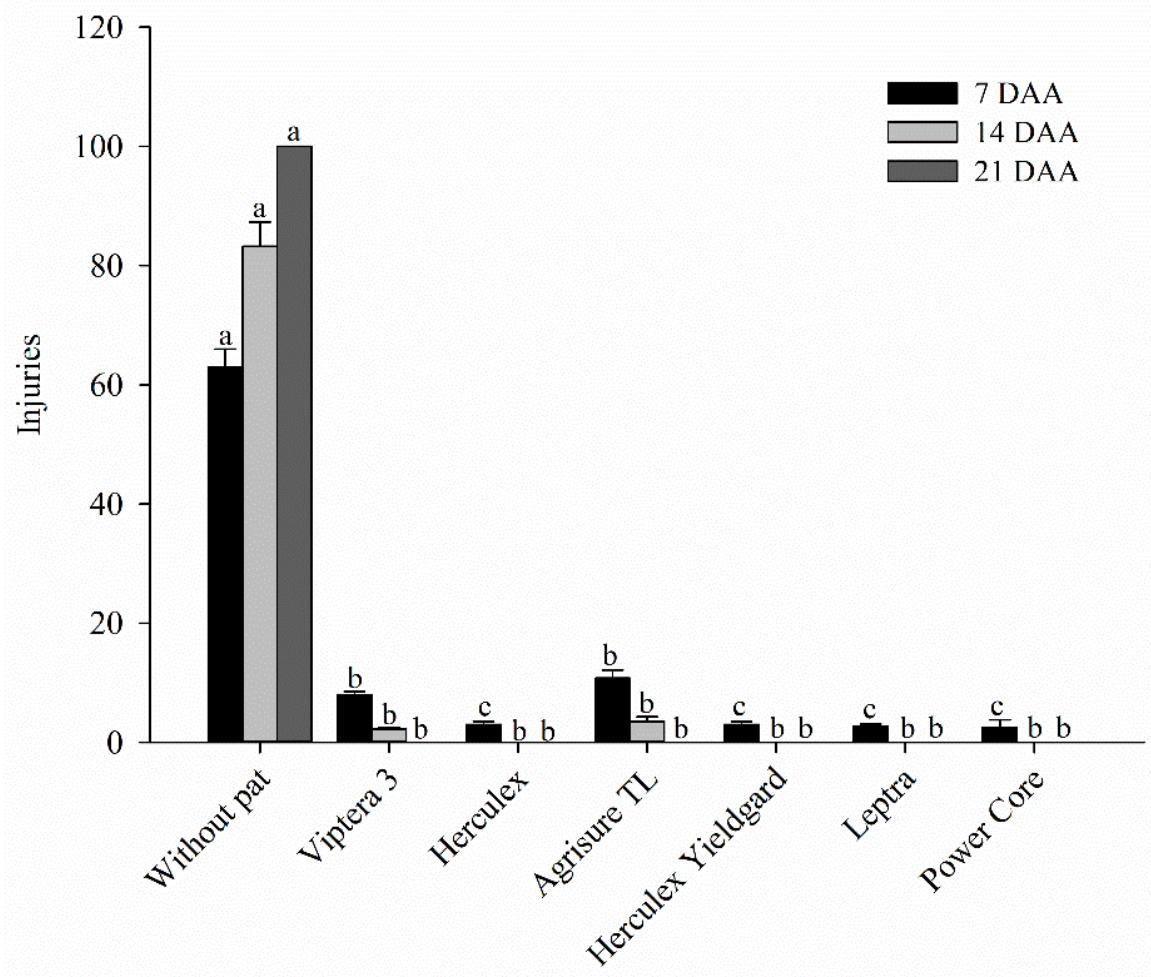

Fig 4. Percentage of injuries in plants of seven maize hybrids subjected to application of $500 \mathrm{~g} \mathrm{ha}^{-1}$ of glufosinate in relation to the control (without glufosinate application) evaluated at 7, 14, and 21 days after application. pat = phosphinothricin acetyltransferase gene. Bars with the same letters (comparing evaluation times or maize hybrids) did not differ by the $t$ test (LSD) $(p<0.05)$. Mean \pm confidence interval. 


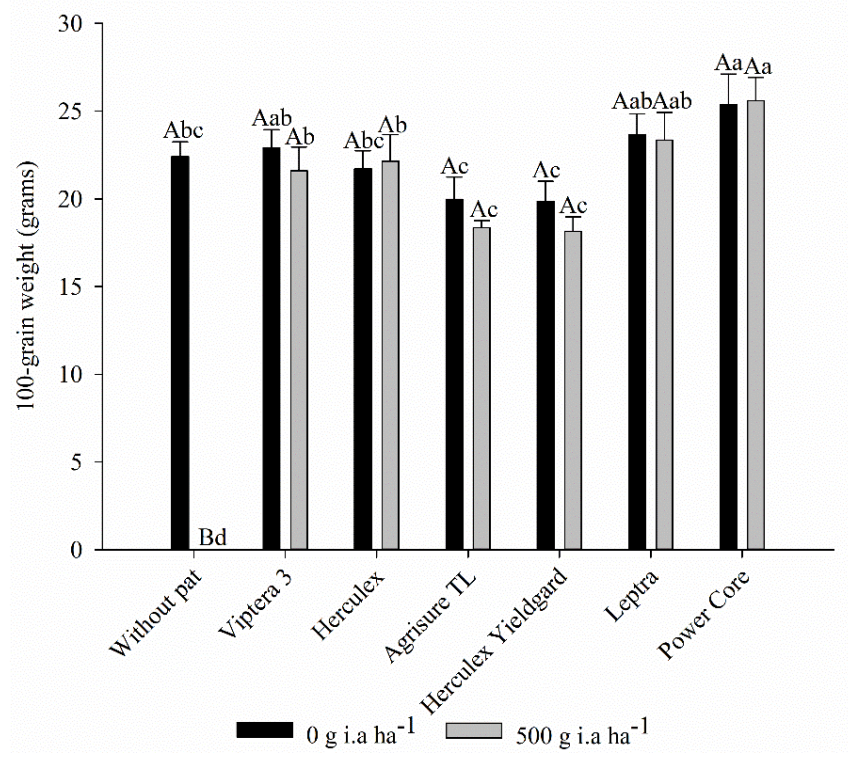

Fig 5. 100-grain weight (g) of plants of seven maize hybrids grown without and with application of glufosinate $\left(500 \mathrm{~g} \mathrm{ha}^{-1}\right)$. pat $=$ phosphinothricin acetyltransferase gene. Bars with the same lowercase letters (comparing maize hybrids) or uppercase letters (comparing rates of glufosinate within each maize hybrid) did not differ by the $t$ test (LSD) $(p<0.05)$. Mean \pm confidence interval.

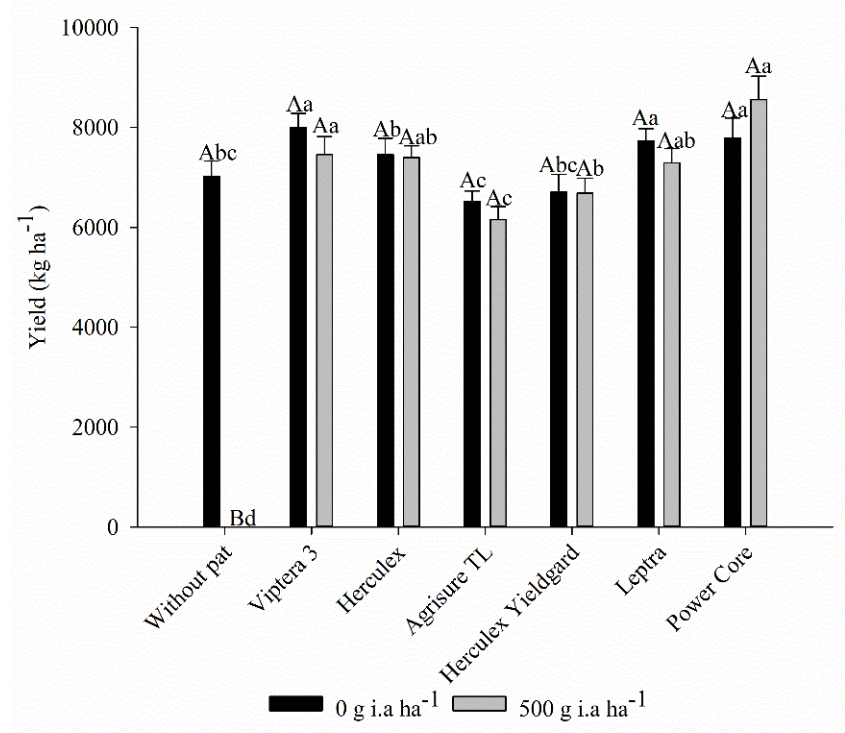

Fig 6. Grain yield $\left(\mathrm{kg} \mathrm{ha}^{-1}\right)$ of plants of seven maize hybrids grown without and with application of glufosinate $\left(500 \mathrm{~g}\right.$ ha $\left.{ }^{-1}\right)$. pat $=$ phosphinothricin acetyltransferase gene. Bars with the same lowercase letters (comparing maize hybrids), or uppercase letters (comparing rates of glufosinate within each technology) did not differ by the $t$ test (LSD) $(p<0.05)$. Mean \pm confidence interval.

The LibertyLink ${ }^{\bullet}$ technology (bar gene) presented greater gene expression than the WideStrike technology (pat gene) and, consequently, the LibertyLink technology presented greater resistance to glufosinate (Carbonari et al., 2016).

\section{Yield parameters in maize hybrids}

The 100-grain weight and grain yield of the evaluated glufosinate-resistant maize plants subjected to application of $500 \mathrm{~g} \mathrm{ha}^{-1}$ of glufosinate and of their control plants without glufosinate application presented no significant differences. Only the glufosinate-susceptible maize plants had significant differences in 100-grain weight and grain yield due to the glufosinate application, since the treatment with glufosinate application resulted in total death of these plants. The Viptera-3, Leptra, and Power-Core hybrids had the highest 100-grain weight and grain yield, regardless of the glufosinate application (Fig 5 and 6). Other studies also found no grain yield reductions for the Power-Core technology after applying $500 \mathrm{~g} \mathrm{ha}^{-1}$ (Krenchinski et al., 2018a; Silva et al., 2017). Maize plants have high recovery potential from damages caused by herbicides, avoiding decreases in grain yield even when they have high percentages of injuries (Krenchinski et al., 2018a, Albrecht et al., 2017; Silva et al., 2017), which favors weed management in these crops.

Plants from the Viptera-3 and Agrisure-TL hybrids had reductions in ETR (Fig 3) and higher ammonia accumulation and percentage of injuries (Fig 2 and 4) than the other evaluated glufosinate-resistant maize hybrids; however, these damages caused no reductions in grain yield and 100grain weight (Fig 5 and 6). Therefore, maize hybrids from the 
Bt11 and TC1507 events, which present the pat gene as a selection marker, are resistant to application of glufosinate herbicide at rate of $500 \mathrm{~g} \mathrm{ha}^{-1}$.

\section{Materials and Methods}

\section{Place of the experiments}

Two field experiments were conducted in different sites in the 2016/2017 crop season. The experiments were carried out in Botucatu, SP, Brazil (22 $\left.50^{\circ} 38.7^{\prime \prime} \mathrm{S} 48^{\circ} 25^{\prime} 29.2^{\prime \prime} \mathrm{W}\right)$ and São Manuel, SP, Brazil $\left(22^{\circ} 46^{\prime} 21.6^{\prime \prime} \mathrm{S} 48^{\circ} 34^{\prime} 07.9^{\prime \prime} \mathrm{W}\right)$, at experimental farms of the São Paulo State University (UNESP). The soil physical and chemical properties of each area are presented in Table 1. Before sowing, a liming was carried out to raise the base saturation to $60 \%$, followed by a harrowing. The soil of both sites was fertilized with $300 \mathrm{~kg}$ $\mathrm{ha}^{-1}$ of the NPK formulation 08-28-16.

\section{Plant materials and treatments}

The experiments were conducted using a randomized block design with a $2 \times 7$ double factorial arrangement (with and without application of glufosinate $\times$ maize hybrids) and four replications. The treatments consisted of applications of water (control treatment) and glufosinate (Finale at $500 \mathrm{~g}$ ai ha ${ }^{-1}$ ), using seven maize hybrids: six containing the pat gene as a selection marker (Herculex, Agrisure-TL ${ }^{\circ}$, Herculex Yieldgard, Leptra , Viptera- $3^{\circ}$, Power-Core $)^{\circ}$; and one without pat (VT PRO ), which was used as control. The maize hybrids were seeded with density of $60,000 \mathrm{ha}^{-1}$ seeds and space between rows of 0.85 meters, in both experimental sites. The seeds were treated with pyraclostrobin and fipronil (Standak Top; $200 \mathrm{ml}$ per $100 \mathrm{~kg}$ of seeds). Pest and disease controls were not necessary during the crop cycle; the plots were kept free of weeds throughout the crop cycle. The herbicide treatments were applied during the V4 phenological stage of maize plants, using a $\mathrm{CO}_{2}$-pressurized backpack sprayer equipped with 6 nozzles with flat jet tips (XR 110.02; Teejet, Wheaton, USA) spaced $50 \mathrm{~cm}$ apart, and set to a constant pressure of 2 BAR (29 PSI), flow rate of 0.65 $\mathrm{L} \min ^{-1}\left(200 \mathrm{~L} \mathrm{ha}^{-1}\right)$, height of $50 \mathrm{~cm}$ from the target, and speed of $1 \mathrm{~m} \mathrm{~s}^{-1}$. The temperature, relative humidity, and wind speed during the herbicide applications were, respectively, $24 \stackrel{\circ}{\circ}$, $66 \%$, and $1.01 \mathrm{~km} \mathrm{~h}^{-1}$ (Botucatu) and 28 oC, $59 \%$, and $1.23 \mathrm{~km} \mathrm{~h}^{-1}$ (São Manuel). The average, maximum, and minimum temperatures, and precipitation during the experiments are described in Fig 1.

\section{Traits measured}

The percentage of injuries caused by the glufosinate herbicide were evaluated visually at 7,14 , and 21 days after application (DAA), using percentages from $0 \%$ to $100 \%$, where $0 \%$ corresponds to no injuries in the plants, and $100 \%$ corresponds to the total death of the plants. Electron transport rate (ETR) was evaluated at 0 and 6 hours after application and also at 1, 2, 3, 5, and 8 DAA, using a portable fluorometer (Multi-Mode Chlorophyll Fluorometer OS5p; Opti Sciences, Hudson, USA); the readings were performed at six points of the youngest fully expanded leaf of each plot. The ETR data of each maize technology were expressed as percentage in relation to the control without application of glufosinate.
Leaves of the plants were taken at 2, 4, and 15 DAA for ammonia extraction. They were cut by the stem, placed in 300-mL labeled tubes, and weighed. The tubes containing the leaves were filled with acidified water by hydrochloric acid (pH 3.5), again weighed and, thein, kept in an ultrasound bath for 60 minutes. The absorbance was determined and the ammonia content in the solution were measured by spectrophotometry, according to methods described by Wendler et al., (1990) and Dayan et al., (2015), using a visible UV double-beam spectrophotometer (Cintra 40, GBC Scientific Equipment Ltd., Braeside, Australia) with wavelength of $630 \mathrm{~nm}$.

Maize ears from the four central meters of the two central rows of each plot were harvested to evaluated grain yield and 100-grain weight. The ears were threshed in an experimental thresher, and samples of grains were cleaned in sieves and placed in paper bags. The grain yield of the plots was used to estimate the grain yield in hectares for each plot. The 100-grain weight was determined by weighing eight subsamples of 100 grains of each plot. Grain yield and 100 -grain weight were calculated considering a grain moisture of $13 \%$ in wet basis.

\section{Statistical analysis}

The data of each experiment were subjected to analysis of variance and, when the $\mathrm{F}$ values were significant $(p \leq 0.05)$, the means were subjected to the T test (LSD) ( $p \leq 0.05)$. Joint analysis of the data of the experiments was also performed. The programs used were Sisvar (version 5.6) and Sigma plot (version 12). The confidence interval (mean \pm confidence interval) was calculated for all evaluated parameters, using the following equation: $\mathrm{Cl}=(t \times S D) / \sqrt{ } n$, where $\mathrm{Cl}$ is the confidence interval; $t$ is the tabulated $\mathrm{t}$ value at $5 \%$ probability level; $S D$ is the standard deviation; and $V n$ is the square root of the number of replications.

\section{Conclusion}

Glufosinate-resistant maize hybrids that have the pat gene (as a selection marker) are resistant to the application of 500 $\mathrm{g} \mathrm{ha}^{-1}$ of glufosinate herbicide, and this practice can be recommended for maize crops.

\section{References}

Albrecht AJP, Albrecht LP, Krenchinski FH, Wobeto KS, Mattiuzzi MD, Eckert CT, Carbonari CA (2017) Assessment of Roundup Ready 2 (RR2) corn subjected to application of isolated and associated herbicides. Aust J Crop Sci. 11(8):974-981.

Armel GR, Richardson RJ, Wilson HP, Hines TE (2008) Mesotrione and glufosinate in glufosinate-resistant corn. Weed Technol. 22(4):591-596.

Barnett KA, Mueller TC, Steckel LE (2012) Glyphosateresistant giant ragweed (Ambrosia trifida) control in WideStrike ${ }^{\circledR}$ flex cotton. Weed Technol. 26(4):611-616.

Brito IP, Marchesi BB, Pucci C, Carbonari CA, Velini ED (2016) Variation in the sensitivities of Hairy Beggarticks (Bidens pilosa) plants and their progenies to glufosinate ammonium. Weed Sci. 64(4):570-578.

Brito IP, Marchesi BB, Silva IPFE, Carbonari CA, Velini ED (2017b) Variation in the sensitivity of wandering jew plants to glufosinate ammonium. Revista Caatinga. 30(3):595601. 
Brito IP, Moraes CP, Marchesi BB, Carbonari CA, Velini ED (2017a) Sensitivity of morningglory plants and their progenies to glufosinate ammonium. Planta Daninha. 35:110.

Carbonari CA, Latorre DO, Gomes GL, Velini ED, Owens DK, Pan Z, Dayan FE (2016) Resistance to glufosinate is proportional to phosphinothricin acetyltransferase expression and activity in LibertyLink ${ }^{\circledR}$ and WideStrike ${ }^{\circledR}$ cotton. Planta. 243(4):925-933.

Coetzer E, Al-Khatib K (2011) Photosynthetic inhibition and ammonium accumulation in Palmer amaranth after glufosinate application. Weed Sci. 49(4):454-459.

Ctnbio (2018) Liberação comercial de plantas de milho. http://ctnbio.mcti.gov.br/liberacao-comercial\#/liberacaocomercial/consultar-processo. (Accessed 21 March, 2018).

Cui Y, Liu Z, Li Y, Zhou F, Chen H, Lin Y (2016) Application of a novel phosphinothricin $\mathrm{N}$-acetyltransferase (RePAT) gene in developing glufosinate-resistant rice. Sci Rep. 6:1-10.

Dayan FE, Duke SO (2014) Natural compounds as next generation herbicides. Plant Physiol. 166(3):1090-1105.

Dayan FE, Cantrell CL, Duke SO (2009) Natural products in crop protection. Bioorg Med Chem. 17(12):402-403.

Dayan FE, Owens DK, Corniani N, Silva FML, Watson SB, Howell JL, Shaner DL (2015) Biochemical markers and enzyme assays for herbicide mode of action and resistance studies. Weed Sci. 63(SP1):23-63.

Dayan FE, Zaccaro ML (2012) Chlorophyll fluorescence as a marker for herbicide mechanisms of action. Pestic Biochem Physiol. 102(3):189-197.

Devine M, Duke SO, Fedtke C (1193) Physiology of herbicide action. $1^{\text {st }}$ edn. Englewood Cliffs, NJ: PTR Prentice Hall. 441 p.

Dröge W, Siemeling U, Pühler A, Broer I (1994) The metabolites of the herbicide L-phosphinothricin (glufosinate): identification, stability, and mobility in transgenic, herbicide-resistant, and untransformed plants. Plant Physiol. 105(1):159-166.

Kleczkowski LA (1993) Inhibitors of photosynthetic enzymes/carriers and metabolism. Annu Rev Plant Physiol Plant Mol Biol. 45(1):339- 367.

Krenchinski FH, Albrecht AJP, Cesco VJS, Rodrigues DM, Pereira VGC, Albrecht LP, Carbonari CA, Victoria Filho R (2018a) Post-emergent applications of isolated and combined herbicides on corn culture with cp4-epsps and pat genes. Crop Prot. 106:156-162.

Krenchinski FH, Carbonari CA, Cesco VJS, Albrecht AJP, Arcuri MDLC, Maia IG, Velini ED (2018b) Glufosinate resistance level is proportional to phosphinothricin acetyltransferase gene expression in glufosinate-resistant maize.J Agric Food Chem. 66(48):12641-12650.
Krenchinski FH, Costa RN, da Cunha Bevilaqua N, Galon JA, de Oliveira JA, Carbonari CA, Velini ED (2018c) Early pruning of eucalyptus plants using glufosinate ammonium. Cerne. 24(3):162-168.

Lutz KA, Knapp JE, Maliga P (2001) Expression of bar in the plastid genome confers herbicide resistance. Plant Physiol 125(4): 1585-1590.

Manderscheid R, Schaaf S, Mattsson M, Schjoerring JK (2005) Glufosinate treatment of weeds results in ammonia emission by plants. Agric Ecosyst Environ. 109(1-2):129140.

Pornprom T, Chompoo J, Grace B (2003) Glufosinate tolerance in hybrid corn varieties based on decreasing ammonia accumulation. Weed Biol Manage. 3(1):41-45.

Reddy KN, Zablotowicz RM, Bellaloui N, Ding W (2011) Glufosinate effects on nitrogen nutrition, growth, yield, and seed composition in glufosinate-resistant and glufosinate sensitive soybean. Int J Agron. 1:1-9.

Ruhland M, Engelhardt G, Pawlizki K (2004) Distribution and metabolism of D/L-, L-and D-glufosinate in transgenic, glufosinate-tolerant crops of maize (Zea mays $L$ ssp mays) and oilseed rape (Brassica napus $\mathrm{L}$ var napus). Pest Manage Sci. 60(7):691-696.

Sauer H, Wild A, Rühle W (1987) The effect of phosphinothricin (glufosinate) on photosynthesis II. The causes of inhibition of photosynthesis. Zeitschrift für Naturforschung. 42(3):270-278.

Sbcpd. 1995. Procedimentos para instalação, avaliação e análise de experimentos com herbicidas. SBCPD: Londrina, Brasil.

Sellers BA, Smeda RJ, Li J (2004) Glutamine synthetase activity and ammonium accumulation is influenced by time of glufosinate application. Pestic Biochem Physiol. 78(1):920.

Silva AFM, Albrecht AJP, Giovanelli BF, Ghirardello GA, Damião VW, Albrecht LP, Victória Filho R (2017) Seletividade de herbicidas isolados e em associações para milho RR2/LL ${ }^{\circledR}$. Rev Bras Herbicidas. 16(1):60-66.

Tan S, Evans R, Singh B (2006) Herbicidal inhibitors of amino acid biosynthesis and herbicide-tolerant crops. Amino Acids 30(2):195-204.

Tsai CJ, Wang CS, Wang CY (2006) Physiological characteristics of glufosinate resistance in rice. Weed Sci. 54(4):634-640.

Wendler C, Barniske M, Wild A (1990) Effect of phosphinothricin (glufosinate) on photosynthesis and photorespiration of $\mathrm{C} 3$ and $\mathrm{C} 4$ plants. Photosynth Res. 24(1):55-61. 